\title{
Female germ unit in Genlisea and Utricularia, with remarks about the evolution of the extra-ovular female gametophyte in members of Lentibulariaceae
}

\author{
Bartosz Jan Plachno
}

Received: 28 May 2010 / Accepted: 14 July 2010 /Published online: 6 August 2010

(C) The Author(s) 2010. This article is published with open access at Springerlink.com

\begin{abstract}
Lentibulariaceae is the largest family among carnivorous plants which displays not only an unusual morphology and anatomy but also the special evolution of its embryological characteristics. It has previously been reported by authors that Utricularia species lack a filiform apparatus in the synergids. The main purposes of this study were to determine whether a filiform apparatus occurs in the synergids of Utricularia and its sister genus Genlisea, and to compare the female germ unit in these genera. The present studies clearly show that synergids in both genera possess a filiform apparatus; however, it seems that Utricularia quelchii synergids have a simpler structure compared to Genlisea aurea and other typical angiosperms. The synergids are located at the terminal position in the embryo sacs of Pinguicula, Genlisea and were probably also located in that position in common Utricularia ancestor. This ancestral characteristic still occurs in some species from the Bivalvaria subgenus. An embryo sac, which grows out beyond the limit of the integument and has contact with nutritive tissue, appeared independently in different Utricularia lineages and as a consequence of this, the egg apparatus changes position from apical to lateral.
\end{abstract}

Keywords Egg apparatus · Synergids · Central cell · Ovule · Ultrastructure · Carnivorous plants · Lentibulariaceae

Handling Editor: Friedrich W. Bentrup

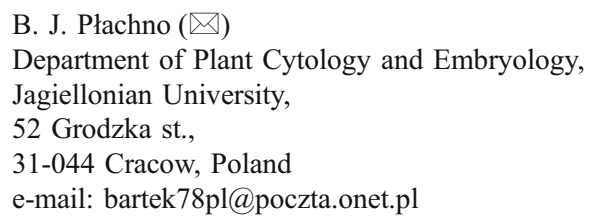

\section{Introduction}

During the growth and guidance of the pollen tube, two phases are distinguished: saprophytic and gametophytic. In the latter, embryo sac (ES; female gametophyte) plays a key role. After experiments on the Torenia fournieri (Higashiyama et al. 2001; 2003), it is widely accepted that synergids are responsible for the attraction of pollen tubes in angiosperms. An embryo sac with two dead synergids did not attract any pollen tubes (Higashiyama et al. 2001).

However, other studies have also suggested that the egg cell and central cell also play a role in the attraction of pollen tubes; e.g., in maize in both the synergids and egg cell, the expression of Zm EA1 gene, which encodes a small (94 amino acids) transmembrane protein needed for proper micropylar pollen tube attraction, was recorded (Marton et al. 2005). In Arabidopsis thaliana female gametophytic central cell guidance mutant, the micropylar pollen tube guidance is absent. Thus, all parts of female germ unit are important in proper pollen tube guidance and bursting to release the sperm cells (Chen et al. 2007). Nevertheless, synergids are essential for the fertilization process of angiosperms (Higashiyama et al. 2001; Punwani and Drews 2008 and reference therein; see also Li et al. 2009). In some plants, e.g., in Plumbago and Plumbagella where synergids are absent, the egg cell takes over the functions of the synergid (Huang et al. 1990) and also possesses a synergid characteristic — a filiform apparatus (Cass 1974; Cass and Karas 1974; Russell and Cass 1988). The filiform apparatus appears to be a universal structure in angiosperms, and even occurs in the synergids of such ancestral like as the Amborella-type female gametophyte (Friedman and Ryerson 2009). However, some rare exceptions also occur, e.g., according to Janson and Willemse (1995) no filiform apparatus was detected in cultivars of Lilium longiflorum, and moreover, no synergid degeneration occurred 
prior to pollen tube penetration. Recently, very interesting hypothesis was proposed that some apomictic species from the Compositae family (genera Chondrilla, Taraxacum) have synergids only in the juvenile phase, which lacks a filiform apparatus, and that this is connected with apomixis (Kościńska-Pająk 2006; Kościńska-Pająk and Bednara 2006). There are, however, arguments against this idea because other studies of apomictic species from other families showed the occurrence of the filiform apparatus (e.g., Jankun 1994; Guan et al. 2007).

Khan (1954), and later Shivaramiah (1967), reported that the Utricularia species (Lentibulariaceae) also lack a filiform apparatus in synergids. Recently, the family Lentibulariaceae has attracted increased scientific interest because of its carnivory (e.g., Adamec 2006; 2007; 2008; Płachno et al. 2007; Płachno and Wołowski 2008; Sirová et al. 2009; 2010), ultra-small haploid genome (Greilhuber et al. 2006), molecular evolution (Jobson et al. 2002; Laakkonen et al. 2006; Müller et al. 2004; Albert et al. 2010), and unusual embryo evolution (Płachno and Świątek 2010). In relation to the morphological and anatomical transformation of vegetative organs, Lentibulariaceae can only compete with river weeds (Rutishauser et al. 1999, 2005; Kirchoff et al. 2008; Ghogue et al. 2009; Koi and Kato 2010) and some parasitic plants. Also in the case of reproduction, Lentibulariaceae and especially the genus Utricularia has many advanced evolutionary characteristics (Khan 1954; Płachno and Świątek 2008; 2009; Płachno et al. 2009). Thus, perhaps the egg apparatus in members of Lentibulariaceae has special characteristics?

The main purposes of this study were to determine whether a filiform apparatus occurs in the synergids of Utricularia and its sister genus Genlisea and to compare the female germ unit in these genera. Another purpose was to examine the evolution of the extra-ovular female gametophyte in members of Lentibulariaceae.

\section{Materials and methods}

Flowers of Genlisea aurea A. St.-Hil. (subgen. Genlisea, Fischer et al. 2000), Chapada dos Guimaraes (Mato Grosso state, Brazil) and Itacambira (Minas Gerais state, Brazil), and Utricularia quelchii N.E.Br. (subgenus Utricularia, Müller and Borsch, 2005), Ilu Tepui (Venezuela), at the anthesis stage were obtained from the greenhouse collection of Kamil Pásek at Dobroslavice (Ostrava, Czech Rep.).

\section{Light and electron microscopy}

For electron microscopy, placentas with ovules were isolated from ovaries and fixed in 2.5\% formaldehyde and $2.5 \%$ glutaraldehyde in a $0.05 \mathrm{M}$ cacodylate buffer $(\mathrm{pH}$ 7.0) for
2 days. The material was postfixed in $1 \% \mathrm{OsO}_{4}$ in a cacodylate buffer for $24 \mathrm{~h}$ at $\sim 4^{\circ} \mathrm{C}$, rinsed in the same buffer, treated with $1 \%$ uranyl acetate in distilled water for $1 \mathrm{~h}$, dehydrated with acetone and embedded in Epon 812 (Fullam, Latham, NY). Semithin sections were stained with methylene blue and examined using an Olympus BX60 microscope. The periodic acid-Schiff (PAS) reaction (Wędzony 1996) was used to detect water insoluble polysaccharides with 1,2-glycol groups. Ultrathin sections were cut on a Leica ultracut UCT ultramicrotome. After contrasting with uranyl acetate and lead citrate, the sections were examined using a Hitachi H500 electron microscope.

\section{Results}

\section{Genlisea aurea (Figs 1, 2, 3, and 4)}

The micropylar canal is very short and partially filled with secretion (Fig. 1a). The micropylar part of synergids extends to the micropylar canal. Synergids are elongated and slightly pear-shaped (Fig. 1b-c). There are small vacuoles in the micropylar pole; whereas, a large vacuole occurs in the chalazal pole (Fig. 1c). The synergid nucleus occurs in a mid-longitudinal position within the cell. The filiform apparatus occurs in both synergids in the micropylar and middle region. It is connected with a common synergid cell wall. It is a sponge-like mass wall material (stained by the PAS reaction), contains some osmiophilic inclusion, and is inter-penetrated by a plasma membrane and cytoplasm with microtubules (Fig. 1d). Both synergids have cytoplasm that is poor in ribosomes in comparison to the egg cell and the central cell. Generally, synergids are also poorer with regard to the presence of organelles in comparison to the central cell. Mitochondria have mainly a perinuclear distribution (Fig. 1b) but also occur near the filiform apparatus. Dictyosomes also occur but they are not active; each dictyosome is composed of up to eight cisternae (Fig. 1e). In the middle part of a synergid, between the central cell and the synergid, there is a typical cell wall with middle lamella and plasmodesmata (Fig. 1f); however, in the direction of the chalazal pole this wall disappears, and pockets of fibril wall material appear between plasma membranes (Fig. 1f). In the chalazal pole of the synergid between the central cell and synergid, there is an irregular layer of wall material-finefibrillar material (Fig. 1g) - which gives a positive result after the PAS reaction (Fig. 2a). This layer also separates the synergid and the central cell on the side of the filiform apparatus (Fig. 2a).

The vase-shaped egg cell is situated below the synergids (Fig. 2b). In the micropylar part of the egg cell, near the attachment of the egg to lateral megagametophyte wall, the wall between the egg cell and the central cell has a middle 
Fig. 1 Ultrastructure of the ovule and embryo sac of $G$. aurea. a Sections through the micropylar canal and the micropylar part of synergids, In integument, $M C$ micropylar canal, sy synergid, bar $=1.2 \mu \mathrm{m}$. b Sections through the micropylar and the central parts of the synergids, $F a$ filiform apparatus, $N$ nucleus, bar $=1.6 \mu \mathrm{m}$. c Chalazal parts of the synergids, $V$ vacuole, Int thick-walled integument cells, bar $=2 \mu \mathrm{m}$. d A part of a filiform apparatus, arrow microtubules, bar $=0.45 \mu \mathrm{m}$. e Synergid cytoplasm with dictyosomes (d), bar $=0.6 \mu \mathrm{m}$. $\mathbf{f}$ middle part of a synergid, the wall between the central cell and the synergid, circle plasmodesmata, $s y$ synergid, $C c$ central cell, $w l$ wall packet, $b a r=0.4 \mu \mathrm{m}$. g Chalazal parts of the synergid, sy synergid, eg egg cell, bar $=1.2 \mu \mathrm{m}$

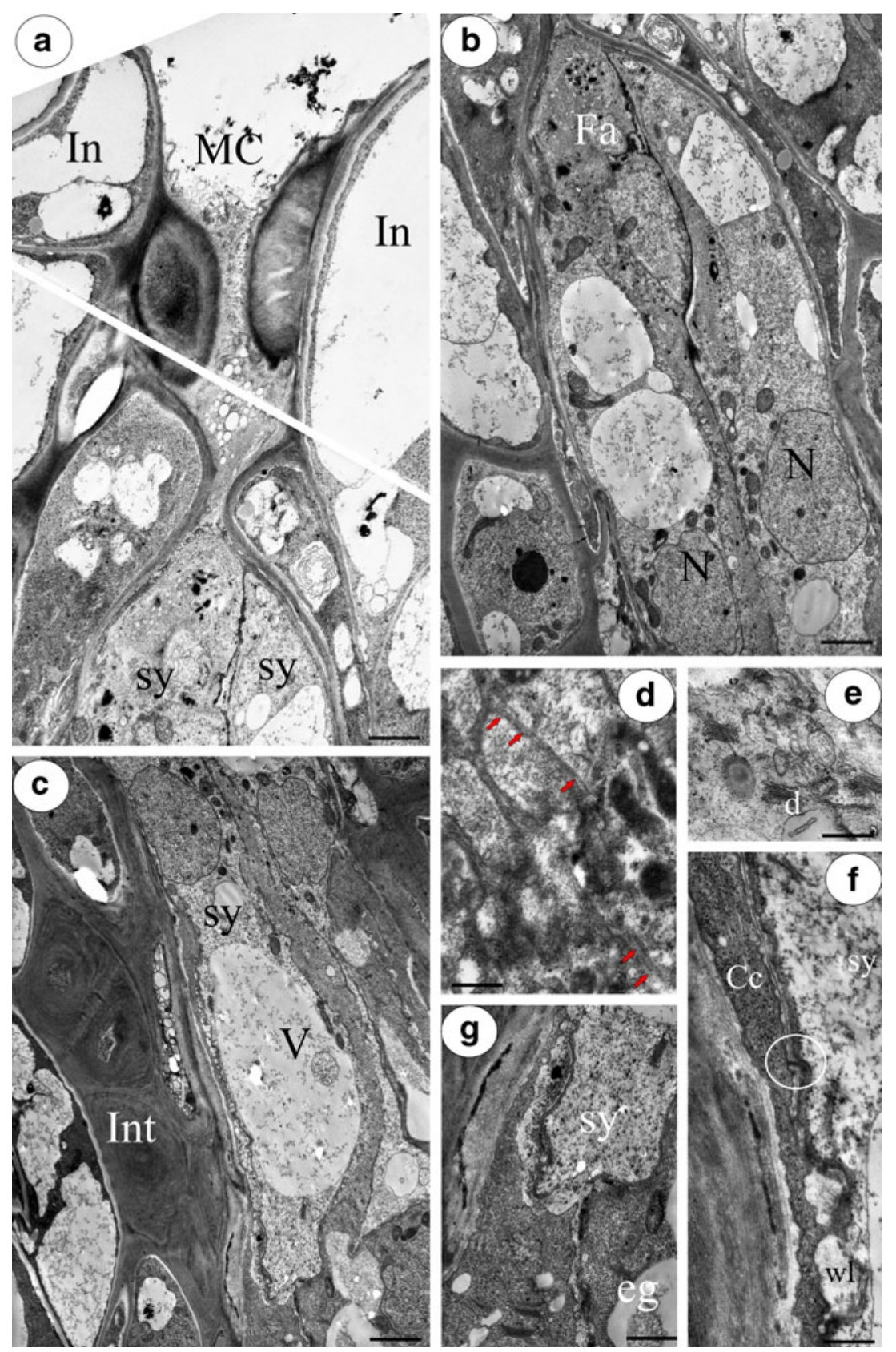

lamella and plasmodesmata (Fig. 2c). In the chalazal pole of the egg cell between the central cell and the egg, there is layer of wall material-fine-fibrillar material that is translucent in the electron matrix (Fig. 2d) - which has a different thickness and gives a positive result after the PAS reaction (Fig. 2a). In some egg cells, osmiophilic deposits are seen in this layer. The micropylar pole of the egg cell is vacuolated (Fig. 2b), but in some egg cells small vacuoles may also occur in a perinuclear position at the chalazal pole. The cytoplasm is rich in ribosomes. Near the nucleus of the egg cell, there are mitochondria, long cisternae of ER, inactive dictyosomes (Fig. 3a), and plastids with dark stroma. In addition, microtubules are clearly visible in the egg cell cytoplasm (Fig. 3b).

The central cell seems to be the most active part of the female gametophyte. Its cytoplasm is full of mitochondria, dictyosomes, and plastids (Fig. 3c-d), and also in the micropylar part (Fig. 2b). The dictyosomes are very active in the production of large vesicles with an electrontranslucent context; these vesicles fuse forming vacuoles. endoplasmic reticulum (ER) and microbodies also occur. Large polar nuclei occur near the vicinity of the egg cell (Fig. 3c); they later fuse creating a secondary nucleus (Fig. $4 a-b)$. There are numerous microtubules in the 
Fig. 2 Anatomy and ultrastructure embryo sac of a $G$. aurea. a Egg apparatus after PAS reaction, note PAS-positive wall on the chalazal part of the egg cell (white arrow) and synergid (black arrow), bar=4 $\mu \mathrm{m}$; b egg apparatus $\mathrm{Fa}$ filiform apparatus, $s y$ synergid, eg egg cell, red arrows attachment of egg wall to the wall of the embryo sac, $C c$ central cell, $b a r=1.7 \mu \mathrm{m}$; c wall between the central cell and the egg cell, circle plasmodesmata, eg egg cell, $b a r=0.4 \mu \mathrm{m}$; d the micropylar part of egg cell, eg egg cell, $C c$ central cell, bar $=1 \mu \mathrm{m}$
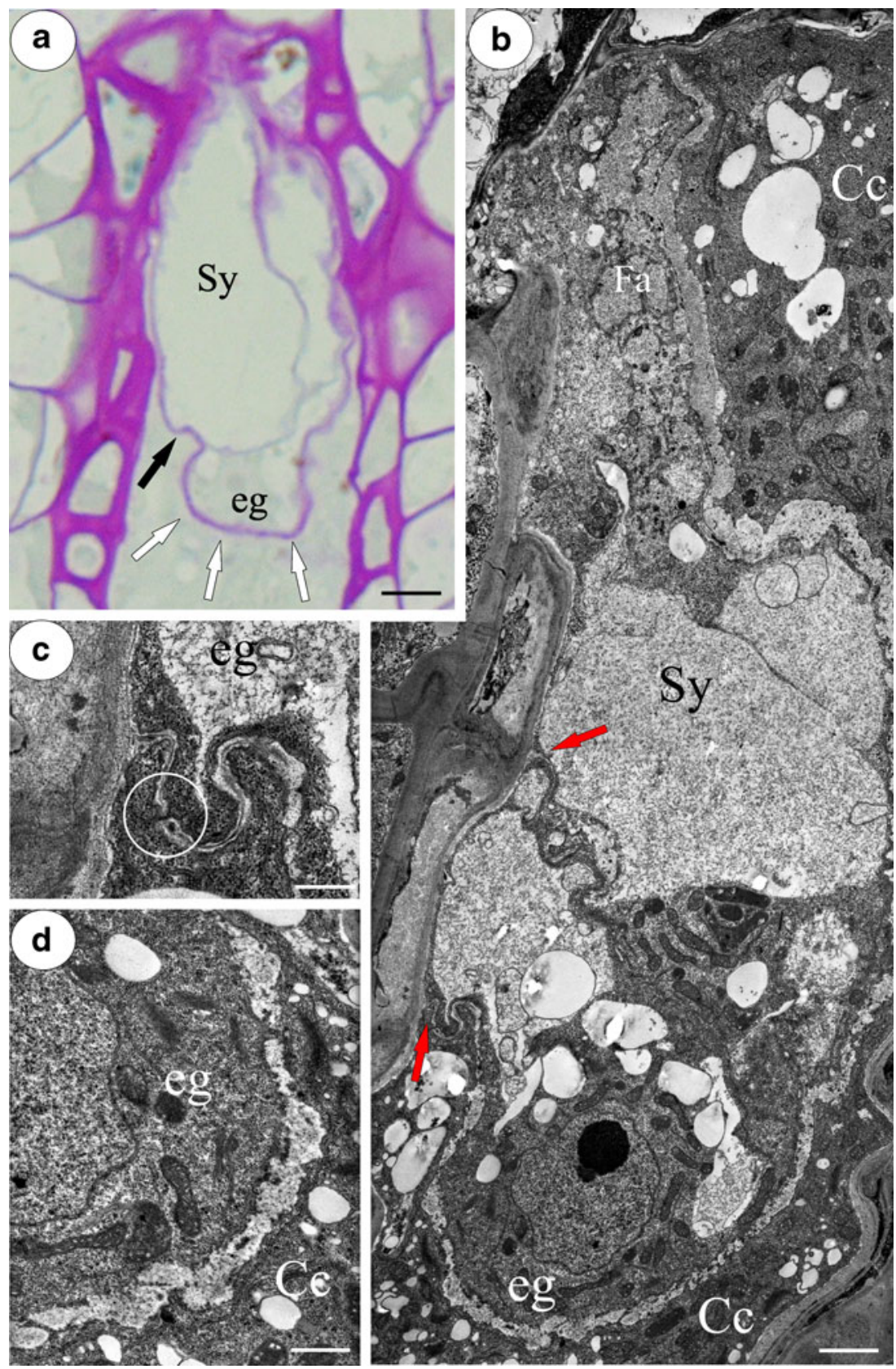

cortical cytoplasm there are numerous microtubules (Fig. 4c), some of them lying parallel to the plasma membrane. The central cell is highly vacuolated in the chalazal part (not shown).

\section{Utricularia quelchii (Figs 5, 6, and 7)}

The ovule is very small, tenuinucellate, and unitegmic. The integument is merged with the funicle forming a raphe. The embryo sac is extended and slightly curved. In the middle part, it borders the integumental tapetum. The most impressive part of the mature embryo sac is the micropylar part of the central cell which projects out beyond the limit of the integument and forms a bulbous apex which grows in the placenta nutritive tissue (Fig. 5a) which is a spherical group of colenchymatous cells that differentiates near the base of the ovule. Thus, a pocket filled with embryo sac is formed in the placenta. This micropylar part of the central cell has a large vacuole traversed by cytoplasmic strands (Fig. 5b) with many mitochondria. The outer cytoplasm is rich in ribosomes; there are also mitochondria, cisternae, and tubules of ER, dictyosomes, microbodies, and lipid bodies. Microtubules are seen (Fig. 5c) near branched tubules of ER. Placental cells in contact with embryo sac are crushed and their remnants are clearly visible. The micropylar part of the central cell has contact with the 
Fig. 3 Ultrastructure of a $G$. aurea egg cell and central cell. a Micropylar part of egg cell, Egn egg nucleus, $m$ mitochondrion, $d$ dictyosome, $P$ plastid, $b a r=0.9 \mu \mathrm{m} ; \mathbf{b}$ the part of egg cytoplasm with mitochondria and microtubules (red arrows), bar $=0.3 \mu \mathrm{m}$; $\mathbf{c}$ the part of the central cell with polar nuclei $(P n)$, eg egg cell, bar $=1,4 \mu \mathrm{m}$; d the part of central cell cytoplasm with active dictyosomes (d), $v$ vacuole, bar $=0,7 \mu \mathrm{m}$
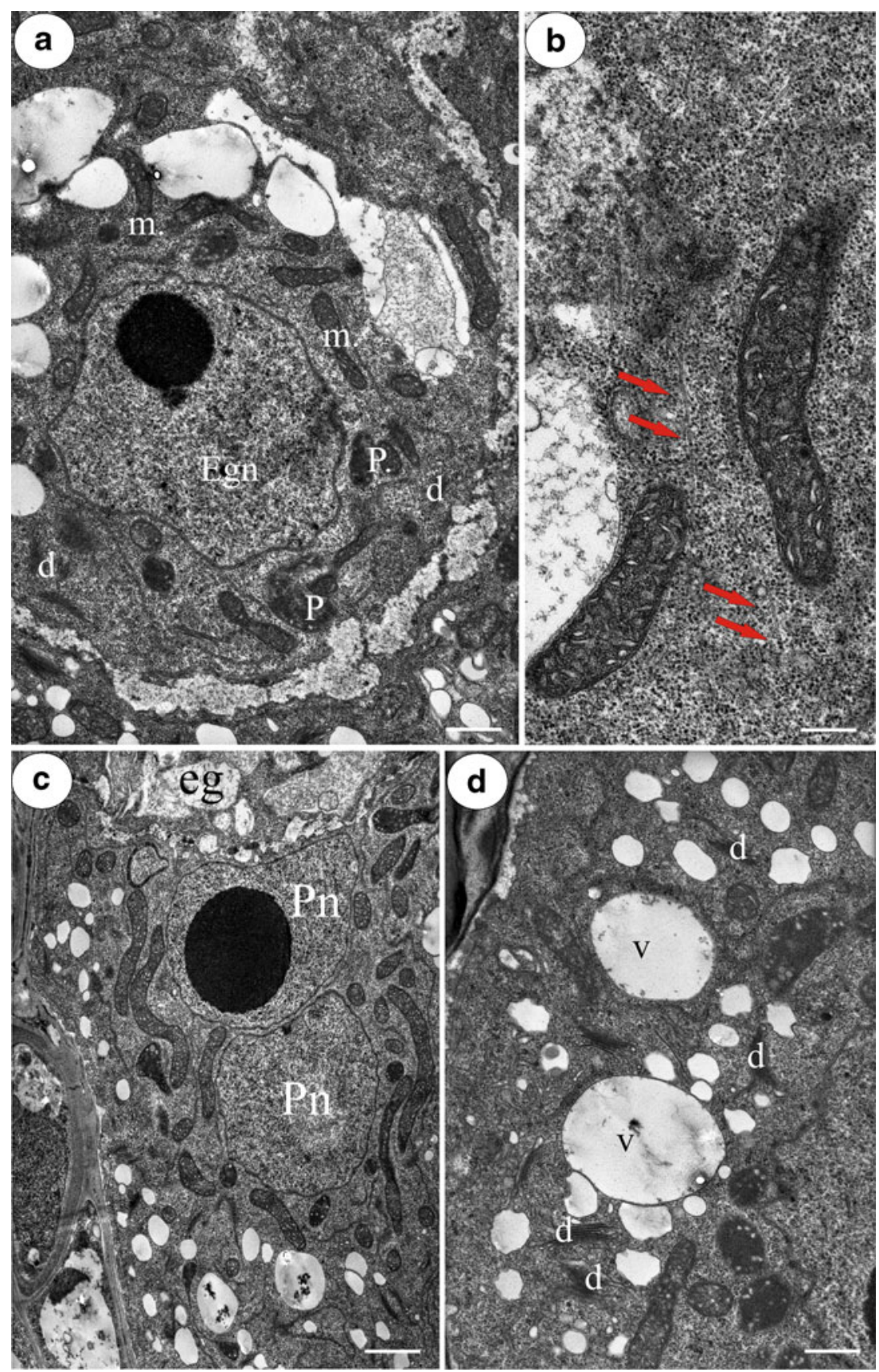

environment of the ovary chamber (Fig. 5d) because between the apex of the integument and the placenta there is a semi-circular slit. This "naked" part of the central cell has a thin layer of peripheral cytoplasm with multivesicular bodies (Fig. 5f). The cell wall here is thin and its external surface is covered by secretion (Fig. 5f).

The egg apparatus is not organized in the micropylar apex but occurs laterally on the raphe side of the embryo sac (Fig. 5a). Synergids occur side by side in the horizontal plane, while the egg cell is situated below them (Fig. 6a). The filiform apparatus occurs in both synergids in the micropylar region. It forms an irregular layer, which consists of a fine-fibrillar material submerged in an electro-translucent matrix (Figs. 5d and 6b). The material of the filiform apparatus is stained intensely by the PAS reaction (Fig. 6a). Plasmalemma and cytoplasm enters the cavities of the filiform apparatus (Fig. 6b). In the synergids, most of the cytoplasm (with dictyosomes, mitochondria, lipids bodies) and nuclei are shifted towards the micropyle, while the chalazal pole is occupied by large vacuole, while the cytoplasm forms only a thin layer between the tonoplast and plasma membrane. The cell wall of synergids is 
Fig. 4 Ultrastructure of a $G$. aurea embryo sac. a Egg cell (eg) central cell with secondary nucleus $(N)$, bar $=1.8 \mu \mathrm{m}$. b The part of central cell cytoplasm with secondary nucleus, plastids $(P)$, mitochondria $(m)$, dictyosomes $(d)$, bar $=0.9 \mu \mathrm{m}$. c The part of the central cell cytoplasm with numerous cortical microtubules (red arrows), bar $=0.2 \mu \mathrm{m}$
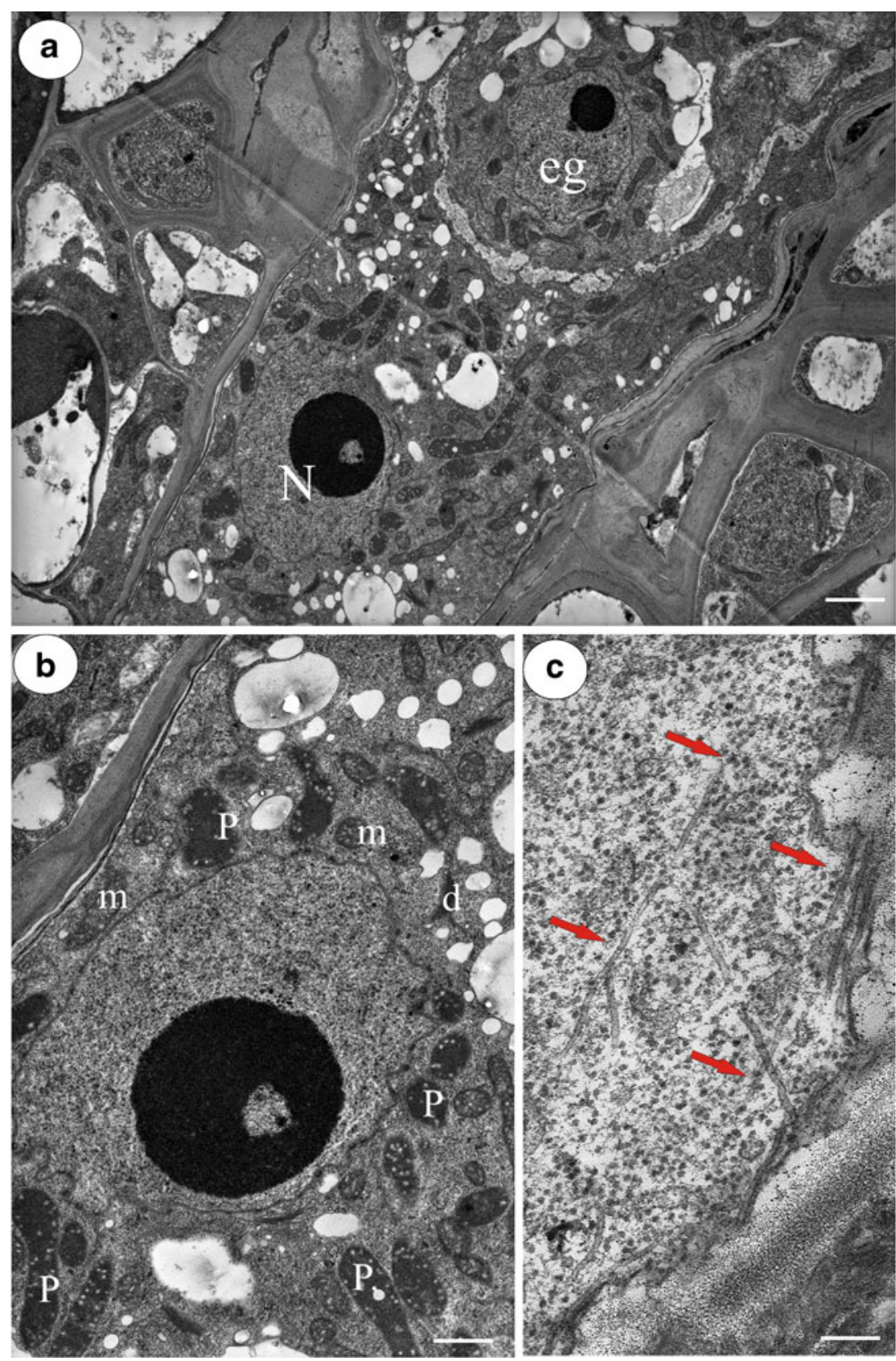

thickest in the micropylar region where it is contiguous with the filiform apparatus, and then this wall becomes thinner towards the chalaza. Between the central cell and the chalazal part of the synergid there is only a very narrow zone between the two plasma membranes of these cells (Fig. 6c) with microtubules occurring near the plasma membrane in the cytoplasm of the central cell.

The egg is vase-shaped and characteristically hooked (Fig. 6d). In the micropylar part of the egg cell, near the attachment of the egg to lateral megagametophyte wall, plasmodesmata between the egg and the central cell occur (Fig. 6e). Also the micropylar region of the egg cell adjacent to the synergid has a well-developed cell wall with plasmodesmata (Fig. 6f). The egg nucleus and the majority of the egg cytoplasm (which is rich in ribosomes) are located in the chalazal region of the cell with the micropylar and the middle parts of the cell which are occupied mostly by vacuole (Fig. 6d). Mitochondria, large lipid bodies, convoluted plastids (proplastid type), dictyosomes (Fig. 7a) are situated in the perinuclear chalazal region of the egg cell. ER cisternae lie parallel to the plasma membrane of the egg cell. Microtubules also occur near the surface membrane of the egg cell (Fig. 7a, framed part). There is an electrontranslucent space filled with membranous material (Fig. 7a) 
Fig. 5 Anatomy of the ovule and embryo sac of $U$. quelchii. a Sections through placenta with ovule; $P$ placenta, $N t$ nutritive tissue, In integument, sy synergid, eg egg cell, $C c$ central cell, bar $=12 \mu \mathrm{m}$. b Sections through thick-walled nutritive tissue $(N t)$ and the extra-ovular part of the central cell $(C c), b a r=3 \mu \mathrm{m}$. $\mathbf{c}$ The part of the extra-ovular central cell cytoplasm; $m$ mitochondrion, $L$ lipid body, $d$ dictyosome, $P$ placental cell, red arrows microtubules, bar $=0.7 \mu \mathrm{m}$. d The micropylar part of the embryo sac; In integument, sy synergid, $C c$ central cell, $\mathrm{Fa}$ filiform apparatus, $W$ secretion, framed part shown in Fig. e, $b a r=2 \mu \mathrm{m}$. e Extra-ovular "naked" part of the central cell; $m v$ multivesicular body, $P$ placenta, bar $=0.6 \mu \mathrm{m}$
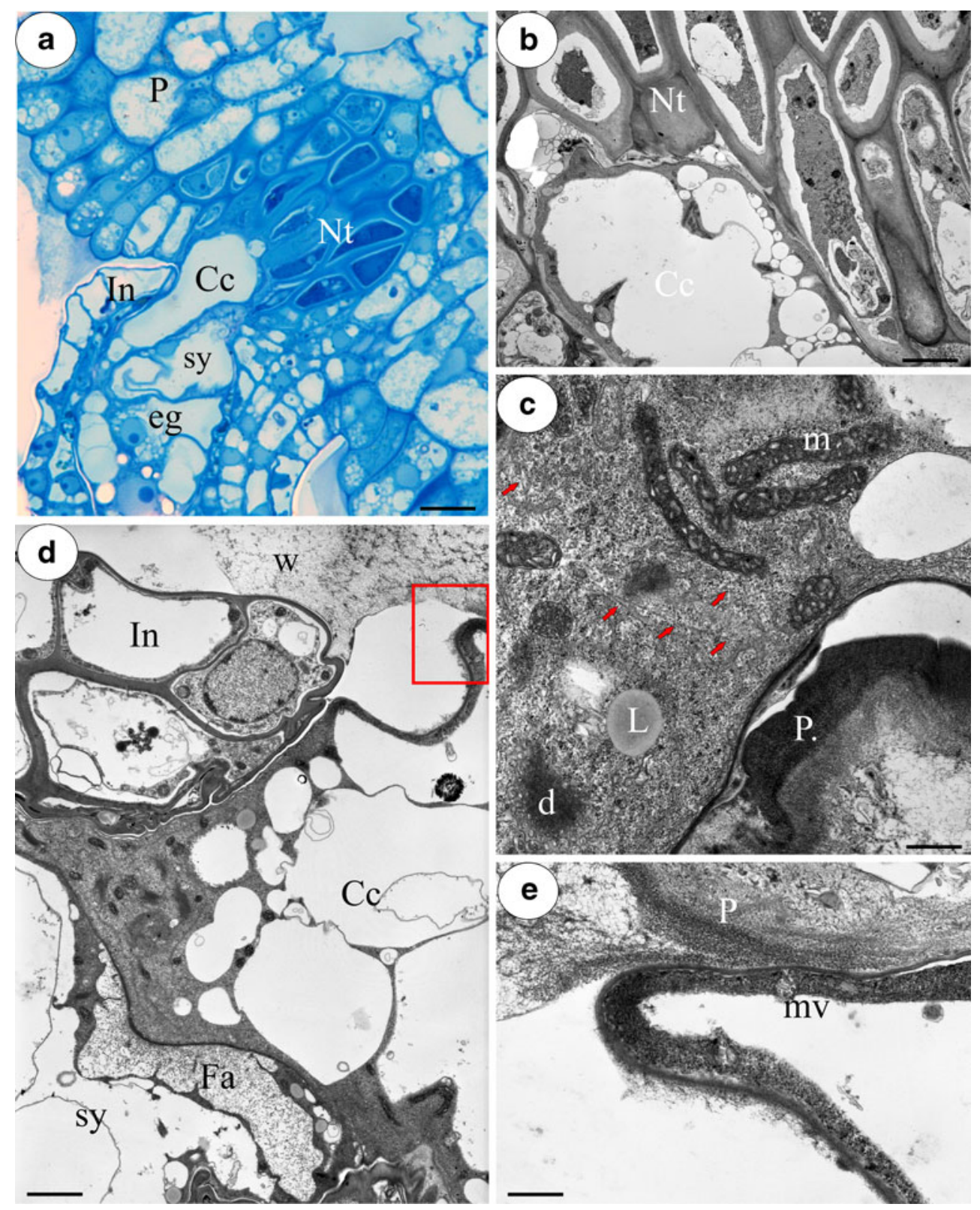

between the plasma membranes of the egg cell and central cell, and in some places this space gives a PAS-positive reaction. This space has a different thickness, thus sometimes the plasma membranes are tightly appressed (Fig. 7a).

Near the vicinity of the egg cell, the first polar nuclei which after fusing (Fig. 7b) give a large secondary nucleus occur (Fig. 7c), and perinuclearly there are amyloplasts with starch, lipids bodies, mitochondria, and dictyosomes (Fig. 7c). The chalazal part of central cell is strongly vacuolated. The micropylar part of central cell which has contact with synergids deserves special attention; its cytoplasm is rich in ER, mitochondria, dictyosomes producing small-coated vesicles (Fig. 5d). An amyloplast with starch can also occur (Fig. 6a).

\section{Discussion}

The position of the egg apparatus and behavior of embryo sac

In most angiosperm plants, synergids occur in the extreme end of female gametophyte below micropylar canal and this position guarantees that one of the synergids will be the first female gametophyte cell that the contact with a pollen tube (Huang and Russell 1992). Of course, it seems logical that the terminal position of synergids is linked with the secretion of pollen tube attractants. The terminal position of synergids is also typical for Lamiales to which Lentibulariaceae belongs (Jobson and Albert 2002; Jobson et al. 2003; 
Fig. 6 Anatomy of the ovule and embryo sac of $U$. quelchii. a Section through the part of placenta with the ovule in the horizontal plane, arrows indicate parts of the central cell which grows into the ovary chamber; $N t$ nutritive tissue, In integument, $S y$ synergid, $\mathrm{Fa}$ filiform apparatus, eg egg cell, $C c$ central cell, bar $=6 \mu \mathrm{m}$. b The micropylar part of the synergid; $S y$ synergid, $C c$ central cell, $m$ mitochondrion,

$L$ lipid body, $d$ dictyosome, $\mathrm{Fa}$ filiform apparatus, bar= $0.9 \mu \mathrm{m}$. c The chalazal part of the synergid; arrows depict the narrow zone between the two plasma membranes of the synergid and the central cell, Sy synergid, Cc central cell, bar $=0.7 \mu \mathrm{m}$. d Ultrastructure of the egg cell and the central cell; Eg egg cell, red arrows attachment of the egg wall to the wall of the embryo sac; $C c$ central cell, framed parts shown in Fig. $\mathrm{E}$ (blue) and F (red) bar $=2 \mu \mathrm{m}$. e The cell wall between the egg cell and the central cell; Eg egg cell, $C c$ central cell, circle plasmodesmata, $b a r=0.9 \mu \mathrm{m}$. e The cell wall between the egg cell and the central synergid; Eg egg cell, circle plasmodesmata, bar $=0.35 \mu \mathrm{m}$

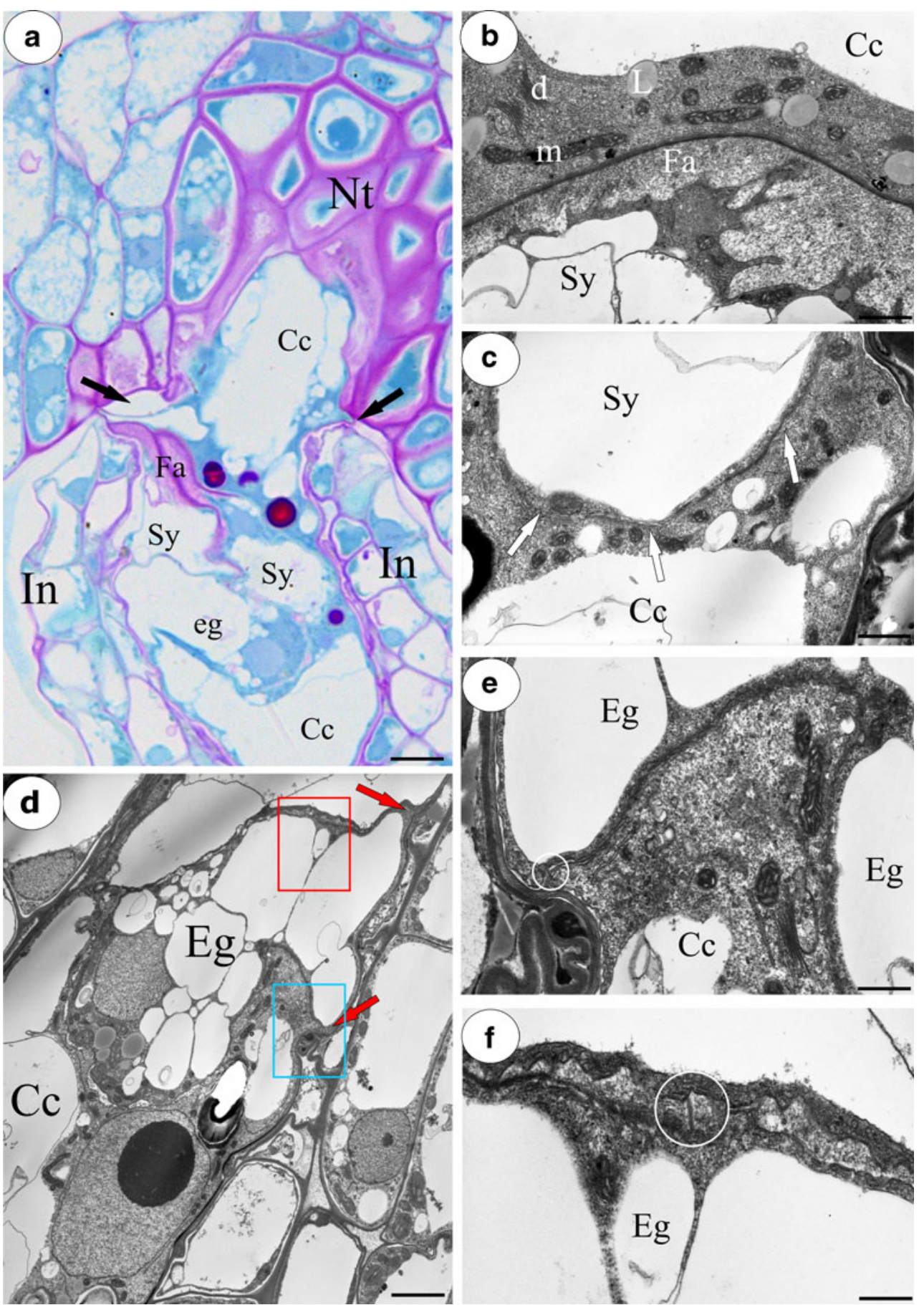

Müller et al. 2000, 2004), e.g., see position of egg apparatus in Proboscidea louisianica (Mogensen 1978) and Orobanchaceae (Fig. 12 in Teryokhin and Nikiticheva 1981). Extreme examples in Lamiales are the genus Torenia and some species of Lindernia in which the egg apparatus is extra-ovular (Krishna Iyengar 1941; Higashiyama et al. 2006). If we look at the Lentibulariaceae family from a phylogenetic point of view, we find that in Pinguicula, which is a sister to Genlisea-Utricularia clade (Jobson and Albert 2002; Jobson et al. 2003; Müller et al. 2004; Müller and Borsch 2005), a micropylar canal occurs and the egg apparatus has an apical position in the embryo sac (Merz 1897; Kopczyńska 1964). In Genlisea, the micropylar canal also occurs in the ovule (Merl 1915), and as it is shown, the micropylar part of synergids extends the to micropylar canal. In the genus Utricularia the situation is more complicated (Table 1). Based on embryological characteristics, Farooq (1965) had already noted that among Utricularia he could distinguish two main groups, as well as Utricularia coerulea, which bears characteristics of both groups. 
Fig. 7 Ultrastructure of a $U$. quelchii egg cell and central cell. a The micropylar part of the egg cell; Eg egg cell, En egg nucleus, $m$ mitochondrion, $d$ dictyosome, $P$ plastid, $C c$ central cell, framed part shows microtubules near the egg plasma membrane, $b a r=0.6 \mu \mathrm{m}$. b Polar nuclei during fusion; red arrows nuclear bridges, $m$ mitochondrion, $d$ dictyosome, bar $=0.4 \mu \mathrm{m}$. c The central cell with a secondary nucleus; $m$ mitochondrion, $S$ starch grain in an amyloplast, $N$ secondary nucleus, bar $=0.9 \mu \mathrm{m}$
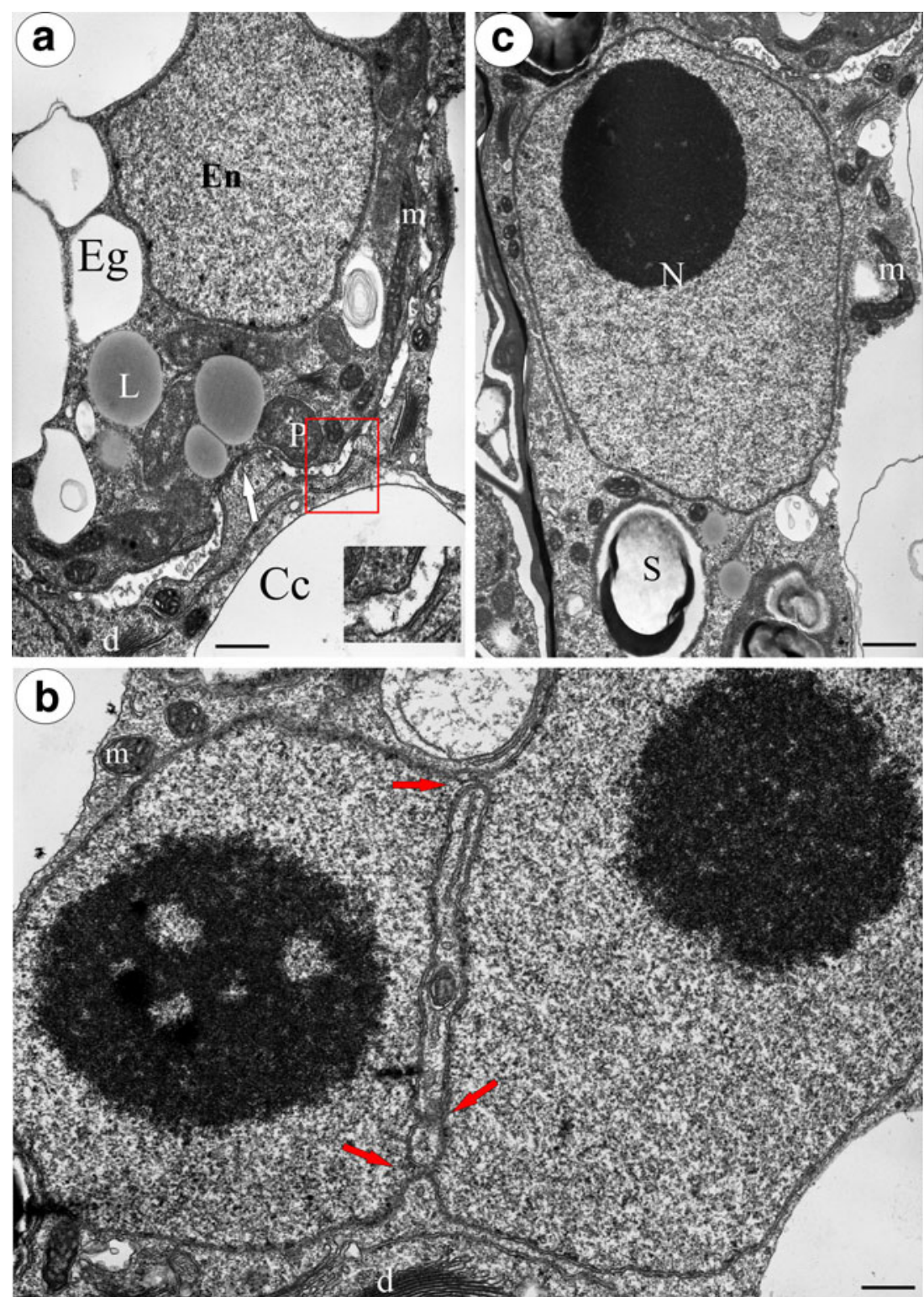

However, he probably did not know the papers of Merz (1897) and Merl (1915). The first group consisted of Utricularia uliginosa, Utricularia arcuata, Utricularia reticulata (terrestrial species); the second Utricularia inflata, Utricularia aurea, Utricularia macrorhiza (aquatic species). Later, Siddiqui (1978b) proposed that Utricularia dichotoma has some embryological characteristics which resemble the aquatic species.

Considering what is currently known about the Utricularia phylogeny (Jobson and Albert 2002; Jobson et al. 2003; Müller and Borsch 2005) and embryo sac characteristics in this genus (Table 1), we can see that in all of the Utricularia species examined, irrespective of either section or subgenus, the ES surpasses the entire micropylar canal; however, the behavior of the ESs is different among species and this characteristic depends on the sectional position.
According to Jobson and Albert (2002), the clades that comprise section Polypompholyx and section Pleiochasia form a monophyletic lineage which is a sister to the clade that includes all of the other sections of Utricularia. Nevertheless, in this lineage the embryo sac extends beyond the limit of integument and the egg apparatus generally occurs in the lateral position on the funicular side (section Pleiochasia, see Siddiqui 1978a). Therefore, the position of the egg apparatus differs from what was reported in Pinguicula and Genlisea. The subgenus Polypompholyx is unique in Lentibulariaceae because of its massive funiculus with nutritive tissue (Siddiqui 1978a; Płachno and Światek 2008). It seems that this subgenus is characterized by a mixture of primitive and specialized features. In the subgenus Bivalvaria, in some species from the section Oligocista, the embryo sac is confined within 
Table 1 Behavior of Utricularia embryo sacs and position of egg apparatus, sections according to Taylor (1989), subgenera according to Müller and Borsch (2005)

\begin{tabular}{|c|c|c|c|}
\hline Subgenus & Section & Behavior of embryo sac (ES) and position of egg apparatus & Author/s \\
\hline \multirow[t]{5}{*}{ Utricularia } & Vesiculina & $\begin{array}{l}\text { ES grows out beyond the limit of the integument and } \\
\text { forms bulbous apex which grows in placenta nutritive } \\
\text { tissue. Egg apparatus in the lateral position (U. cucullata, } \\
\text { Utricularia purpurea). }\end{array}$ & Merl 1915, Merz, 1897 \\
\hline & Utricularia & $\begin{array}{l}\text { ES grows out beyond the limit of the integument and } \\
\text { forms bulbous apex which affected placental nutritive } \\
\text { tissue-apex is buried in it. Egg apparatus in the lateral } \\
\text { position (e.g., U. stellaris, U. inflata, U. aurea, } U \text {. } \\
\text { macrorhiza). }\end{array}$ & $\begin{array}{l}\text { eg. Farooq and Siddiqui 1964, Khan 1954, Merz } \\
\text { 1897, Wylie and Yocom } 1923\end{array}$ \\
\hline & Iperua & $\begin{array}{l}\text { ES grows out beyond the limit of the integument and forms } \\
\text { bulbous apex which grows in placenta nutritive tissue } \\
\text { (reniformis reniformis). }\end{array}$ & Merl 1915 \\
\hline & Orchidioides & $\begin{array}{l}\text { ES grows out beyond the limit of the integument and } \\
\text { forms bulbous apex which grows in placenta nutritive } \\
\text { tissue (U. quelchii), or even grows on the surface of } \\
\text { neighboring ovule (Utricularia alpina). Egg apparatus in } \\
\text { the lateral position. }\end{array}$ & This paper, Płachno and Świątek 2008 \\
\hline & Foliosa & $\begin{array}{l}\text { ES grows out beyond the limit of the integument and } \\
\text { has a contact with placenta nutritive tissue (Utricularia } \\
\text { tricolor). }\end{array}$ & Merl 1915 \\
\hline \multirow[t]{4}{*}{ Bivalvaria } & Oligocista & $\begin{array}{l}\text { The ES confines within the ovule or slightly extends the } \\
\text { micropyle, the tip of ES contains egg apparatus } \\
\text { (Utricularia scandens, U. uliginosa, U. smithiana, } \\
\text { U. reticulata). } \\
\text { The tip of ES contains egg apparatus, however, protrudes } \\
\text { out of micropyle and has contact with the nutritive tissue } \\
\text { (Utricularia graminifolia). }\end{array}$ & $\begin{array}{l}\text { Farooq 1965, Rajan and Kumar 1974, } \\
\text { Shivaramiah 1967, Farooq and Bilquis 1966, } \\
\text { Begum 1965, Kausik and Raju } 1955\end{array}$ \\
\hline & & $\begin{array}{l}\text { The micropylar apex of ES becoming extra-ovular, the egg } \\
\text { apparatus is situated below it (Utricularia polygaloides). }\end{array}$ & \\
\hline & Calpidisca & $\begin{array}{l}\text { The micropylar end of ES slightly extends beyond the limit } \\
\text { of integument and touches the funicular nutritive tissue. } \\
\text { Synergids in apical part of the ES (Utricularia livida, } \\
\text { Utricularia sandersonii). }\end{array}$ & Płachno 2002 \\
\hline & Nigrescentes & $\begin{array}{l}\text { ES grows out beyond the limit of the integument and } \\
\text { forms bulbous apex which grows in placenta nutritive } \\
\text { tissue, the egg apparatus is beyond the micropyle- } \\
\text { exposed (U. coerulea). }\end{array}$ & Kausik 1938 \\
\hline \multirow[t]{2}{*}{ Polypompholyx } & Pleiochasia & $\begin{array}{l}\text { The micropylar end of ES slightly extends beyond the } \\
\text { limit of integument and touches epidermis of the funicular } \\
\text { nutritive tissue (Utricularia menziesii, } U \text {. dichotoma). } \\
\text { Generally egg apparatus in the lateral position }(U \text {. } \\
\text { dichotoma). }\end{array}$ & $\begin{array}{l}\text { Merl 1915, Siddiqui 1978a, Płachno and Świątek } \\
2008\end{array}$ \\
\hline & Polypompholyx & $\begin{array}{l}\text { The micropylar end of the ES extends beyond the limit } \\
\text { of integument and touches epidermis of the funicular } \\
\text { nutritive tissue. }\end{array}$ & Lang 1901 \\
\hline
\end{tabular}

the ovule or slightly extends the micropyle, and its tip contains the egg apparatus (Table 1), and in this characteristic is similar to Pinguicula and Genlisea. However, in the same subgenus in section Nigrescentes, $U$. coerulea has an extra-ovular egg apparatus (Kausik 1938). But, species from sections: Oligocista, Stomoisia, Nigrescentes, and Calpidisca are linked by the development of the endosperm - in all these sections the endosperm bends in the shape of a horseshoe (Farooq 1965; Siddiqui 1979; Płachno 2002).
The fact that the embryo sac in aquatic species (section Utricularia) is aggressive and invades the placental nutritive tissue at the 4-nucleate stage was well known (Khan 1954; Farooq and Siddiqui 1964; Farooq 1965). Here, it is clear that also in section Orchidioides, the embryo sac is aggressive in relation to the placental nutritive tissue. So, in the subgenus Utricularia, whichever ecological groups are investigated (aquatic, epiphytic, litophytic), the egg apparatus has the lateral position (Table 1). However, there is still lack of information about 
some other sections, e.g., it would be very interesting to know the behavior of the embryo sac in terrestrial species from section Setiscapella from the subgenus Utricularia.

Why and how did the extra-ovular embryo sacs evolve in Utricularia? It seems that this process occurred in a step-bystep process. In a common ancestor of the GenliseaUtricularia clade, a micropylar canal existed and the embryo sac remained inside the ovule, while the egg apparatus had apical position. The first step, the embryo sac of the common ancestor of Utricularia filled the entire micropylar canal, but did not grow out beyond the limit of the integument. The egg apparatus had an apical position. This condition still occurs in some members of the subgenus Bivalvaria (Table 1). However, independently in different Utricularia lineages an embryo sac appeared which grows out beyond the limit of the integument and has contact with nutritive tissue. The advantage of this stage was the development of another pathway of metabolite transport directly from the placental (funicular in Polypompholyx) nutritive tissue to the embryo sac (Khan 1954, 1992; Płachno and Światek 2008). As a consequence of the extra development of the micropylar part of the embryo sac (central cell), the egg apparatus changed position from apical to lateral.

In angiosperms, the haustoria of embryo sacs have been recorded in about 20 families; however, the most common are the chalazal, but the micropylar such as those in Utricularia are rare (Poddubnaya-Arnoldi 1976). It is believed that the enlargement of the central cell increases the abortive surface of the embryo sac (Masand and Kapil 1966). But Czapik
(1987) proposed that formation of the haustorium there is also a process leading to a need for an increase in the volume of the embryo sac before the development of the endosperm and embryo in the Dryas. It seems that this also occurs in Utricularia because species with a well-developed extraovular embryo sac later also have the most well-developed aggressive micropylar endospermal hastorium (and later syncytium; Khan 1954).

\section{Ultrastructure of female germ unit}

It should be highlighted that this paper is the first report about the ultrastructure of the egg apparatus in the Lentibulariaceae family. A comparison of the egg apparatus of G. aurea and $U$. quelchii is given in Table 2 . Surprisingly, the egg apparatus in G. aurea is enclosed in the chalazal part by PAS-positive wall. This situation has been recorded in only a few species of angiosperms: Capsella (Schulz and Jensen 1968), Papaver (Olson and Cass 1981), Epidendrum (Cocucci and Jensen 1969), Ornithogalum (Tilton 1981) and Scilla (Bhandari and Sachdeva 1983). Typically, on the chalazal parts of the synergids and egg cell, only plasma membranes separate these cells from central cell (Huang and Russell 1992). Generally, the ultrastructure of the egg cells of both Genlisea and Utricularia is similar to other plants. However, the eggs cell of Lentibulariaceae contain only a low number of plastids and a small amount of mitochondria in comparison to Impatiens (Richter-Landmann 1959) and Plumbago (Russell 1987). But

Table 2 Comparison between egg apparatus of $G$. aurea and U. quelchii

\begin{tabular}{|c|c|c|c|}
\hline & & G. aurea & U. quelchii \\
\hline \multirow[t]{6}{*}{ Synergids } & Position & Micropylar part of synergid extends to micropylar canal. & $\begin{array}{l}\text { Lack of micropylar canal, egg apparatus is occurs } \\
\text { laterally on the raphe side of the embryo sac. }\end{array}$ \\
\hline & $\begin{array}{l}\text { Filiform } \\
\text { apparatus }\end{array}$ & Occurs & Occurs \\
\hline & Plasmodesmata & Between synergid and central cell & Between synergid and egg cell \\
\hline & Cell wall & $\begin{array}{l}\text { In chalazal pole, there is an irregular layer of PAS-positive } \\
\text { wall material. }\end{array}$ & $\begin{array}{l}\text { In chalazal pole there is only very narrow zone } \\
\text { between two plasma membranes. }\end{array}$ \\
\hline & Vacuole & $\begin{array}{l}\text { Small vacuoles on the middle part, large vacuole in chalazal } \\
\text { pole }\end{array}$ & $\begin{array}{l}\text { Synergid strongly vacuolated }- \text { most of the cell is } \\
\text { filled by vacuole. }\end{array}$ \\
\hline & $\begin{array}{l}\text { Distribution of } \\
\text { organelles }\end{array}$ & Perinuclear distribution and near filiform apparatus & Distribution near filiform apparatus \\
\hline \multirow[t]{5}{*}{ Egg cell } & Plasmodesmata & Between egg cell and central cell & Between egg cell and central cell \\
\hline & & & Between egg cell and synergids \\
\hline & Cell wall & $\begin{array}{l}\text { On micropylar pole typical cell wall is organized. In } \\
\text { chalazal pole, there is an irregular layer of PAS positive } \\
\text { wall material }\end{array}$ & $\begin{array}{l}\text { On micropylar pole typical cell wall is organized. In } \\
\text { chalazal pole, there is a space with some exocytic } \\
\text { vesicles }\end{array}$ \\
\hline & Vacuole & $\begin{array}{l}\text { Occurs in the micropylar part. Small vacuoles may occur } \\
\text { also in perinuclear position at chalazal pole }\end{array}$ & Occurs in the micropylar and middle parts \\
\hline & $\begin{array}{l}\text { Storage } \\
\text { material }\end{array}$ & - & Large lipid bodies \\
\hline
\end{tabular}


a low number of plastids were also observed in Oenothera (Meyer and Stubbe 1974), and a small amount of mitochondria in Petunia and Agave (Tilton 1981).

It is worth mentioning that even in the material that was chemically fixed the microtubules are well preserved in female gametophytes, which is in contrast to the results of Thijssen et al. (1997) who observed microtubules only in high-pressure frozen embryo sacs.

It is presented that the filiform apparatus occurs in both genera Genlisea and Utricularia. So these results are in contrast to the observations of Khan (1954) and Shivaramiah (1967). In Genlisea aurea, the apical position of synergids and the filiform apparatus inside them is similar to other angiosperms (see Fig. 6 in Huang and Russell 1992). This might be connected with the synergid's role in the secretion of attractants for pollen tubes by the filiform apparatus to the micropyle, and later with the penetration of the synergid by the pollen tube (e.g., Diboll and Larson 1966; Went 1970; Higashiyama et al. 2001, 2003; Huang and Russell 1992). The results of this research are in agreement with Merl (1915), who observed porogamy in Genlisea. However, in U. quelchii and some other Utrcularia species, (Table 1) the egg apparatus is not organized in an apical position and this has the following consequences. Firstly, if synergids produce attractants for pollen tubes, these attractants should be transported via the central cell or placenta cells. Secondly, the central cell, not the synergid, is the first female gametophyte cell which has contact with pollen tube. In relation to the first, Merz (1897) described contact of pollen tubes with extra-ovular embryo sacs in Utricularia (U. inflata, Utricularia purpurea, Utricularia stellaris). According to him, a pollen tube enters the central cell and grows inside up to the egg apparatus which is organized on the funicular side of the ovule. In contrast, Khan (1954), in $U$. aurea, did not observe that a pollen tube enters the central cell directly and grows inside this cell. According to him and Farooq (1964), a U. stellaris pollen tube has its first contact with the embryo sac and later grows between the wall of the embryo sac and the placenta surface, and finally reaches the funicular side, enters the embryo sac, and penetrates the synergid. Khan (1954) wondered why in $U$. aurea, if synergids emit chemo-attractants, pollen tubes do not grow directly via the central cell using the shortest route to the synergids.

However, it seems that the synergids in $U$. quelchii have a simpler structure when their ultrastructure is compared with Genlisea (this paper) and other angiosperms (Huang and Russel 1992). In this case, the micropylar part of the central cell which has contact with the synergids of $U$. quelchii deserves special attention. It is very active and I propose that it may be responsible for liaising between a female gametophyte and a pollen tube. It seems that it could take over the functions of the synergid in this aspect. Still, synergids with a filiform apparatus are needed for the pollen tube to properly enter the embryo sac. However, this should be proven by using other techniques. Recently, Marton et al. (2005) showed that the central cell also plays a role in attracting pollen tubes. Another question is why the extra-ovular part of the Utricularia embryo sac is strongly vacuolated. This vacuolization is probably needed to generate the turgor which helps to crush the placental nutritive cells and later absorbs nutrients.

\section{Conclusions}

Synergids in both Genlisea and Utricularia possess a filiform apparatus; however, it seems that the U. quelchii synergids have a simpler structure compared to G. aurea and other typical angiosperms.

The terminal position of synergids occurs in the embryo sacs of Pinguicula, Genlisea and probably occurred in a common Utricularia ancestor. This ancestral characteristic still occurs in some species from the Bivalvaria subgenus. Independently, in different Utricularia lineages, an embryo sac which grows out beyond the limit of the integument and has contact with nutritive tissue has appeared and as a consequence of this, the egg apparatus changes position from apical to lateral.

Acknowledgments This study was funded by grant N N304 002536 from the Polish Ministry of Science and Higher Education. The author gratefully acknowledges the support of an award from the Foundation for Polish Sciences (Start Programme). I am also grateful to Prof. Jerzy Klag and my friend Dr. Piotr Świątek for the opportunity to use the transmission electron microscope in the Department of Animal Histology and Embryology (University of Silesia), and also my colleague Kamil Pásek (Czech Republic, http://www.bestcarnivorousplants.net/) for providing flowers for this study. The comments to the manuscript of Dr. Lubomir Adamec are kindly acknowledged.

Conflict of interest The author declares that he has no conflict of interest.

Open Access This article is distributed under the terms of the Creative Commons Attribution Noncommercial License which permits any noncommercial use, distribution, and reproduction in any medium, provided the original author(s) and source are credited.

\section{References}

Adamec L (2006) Respiration and photosynthesis of bladders and leaves of aquatic Utricularia species. Plant Biol 8:765-769

Adamec L (2007) Oxygen concentrations inside the traps of the carnivorous plants Utricularia and Genlisea (Lentibulariaceae). Ann Bot 100:849-856

Adamec L (2008) Mineral nutrient relations in the aquatic carnivorous plant Utricularia australis and its investment in carnivory. Fund Appl Limnol 171:175-183 
Albert VA, Jobson RW, Michael TP, Taylor DJ (2010) The carnivorous bladderwort (Utricularia, Lentibulariaceae): a system inflates. J Exp Bot 61:5-9. doi:10.1093/jxb/erp349

Begum M (1965) Studies on the embryology of Utricularia graminifolia, Vahl. Curr Sci 34:355-356

Bhandari NN, Sachdeva A (1983) Some aspects of organization and histochemistry of the embryo sac of Scilla sibirica sato. Protoplasma 116:170-178

Cass DD (1974) Occurrence and development of a filiform apparatus in the egg of Plumbago capensis. Am J Bot 59:279-283

Cass DD, Karas I (1974) Ultrastractural organization of the egg of Plumbago zeylanica. Protoplasma 81:49-62

Chen Y-H, Li H-J, Shi D-Q, Yuan L, Liu J, Sreenivasan R, Baskar R, Grossniklaus U, Yang W-C (2007) The Central cell plays a critical role in pollen tube guidance in Arabidopsis. Plant Cell 19:3563-3577

Cocucci A, Jensen WA (1969) Orchid embryology: megagametophyte of Epidendrum scutella following fertilization. Am J Bot 56:629 640

Czapik R (1987) Embryo sac haustorium in Dryas octopetala L. (Rosaceae). Acta Soc Bot Pol 56:209-214

Diboll AG, Larson DA (1966) An electron microscopic study of the mature megagametophyte in Zea mays. Am J Bot 53:391-402

Farooq M (1965) Studies in the Lentibulariaceae III. The embryology of Utricularia uliginosa Vahl. Phytomorphology 15:123-131

Farooq M, Bilquis S (1966) Studies in the Lentibulariaceae 7. The embryogeny in U. scandens Benj. Beitr Biol Pflanz 42:127-131

Farooq M, Siddiqui SA (1964) The embryology of Utricularia stellaris Linn. f. Sci Cult 30:394-395

Fischer E, Porembski S, Barthlott W (2000) Revision of the genus Genlisea (Lentibulariaceae) in Africa and Madagascar with notes on ecology and phytogeography. Nordic J Bot 20:291-318

Friedman WE, Ryerson KC (2009) Reconstructing the ancestral female gametophyte of angiosperms: Insights from Amborella and other ancient lineages of flowering plants. Am J Bot 96:129-143

Ghogue J-P, Ameka GK, Grob V, Huber KA, Pfeifer E, Rutishauser R (2009) Enigmatic morphology of Djinga felicis (PodostemaceaePodostemoideae), a badly known endemic from northwestern Cameroon. Bot J Linn Soc 160:64-68

Greilhuber J, Borsch T, Müller K, Worberg A, Porembski S, Barthlott W (2006) Smallest angiosperm genomes found in Lentibulariaceae, with chromosomes of bacterial size. Plant Biol 8:770777. doi:10.1055/s-2006-924101

Guan LM, Chen LZ, Terao H (2007) Ultrastructural studies of gametophytic apomicts in Guinea Grass (Panicum maximum) II. Characteristics of aposporous initial cell-derived embryo sac. Cytologia 72:145-153

Higashiyama T, Yabe S, Sasaki N, Nishimura Y, Miyagishima S, Kuroiwa H, Kuroiwa T (2001) Pollen tube attraction by the synergid cell. Science 293:1480-1483

Higashiyama T, Kuroiwa H, Kuroiwa T (2003) Pollen tube guidance: beacons from the female gametophyte. Curr Opin Plant Biol 6:36-41

Higashiyama T, Inatsugi R, Sakamoto S, Sasaki N, Mori T, Kuroiwa H, Nakada T, Nozaki H, Kuroiwa T, Nakano A (2006) Species preferentiality of the pollen tube attractant derived from the synergid cell of Torenia fournieri. Plant Physiol 142:481-491

Huang BQ, Russell SD (1992) Female germ unit: organization, isolation, and function. Int Rev Cytol 140:233-293

Huang BQ, Russell SD, Strout GW, Mao LJ (1990) Organization of isolated embryo sacs and eggs of Plumbago zeylanica (Plumbaginaceae) before and after fertilization. Am J Bot 77:1401-1410

Jankun A (1994) Embryological studies in Sorbus intermedia (Rosaceae). Pol Bot Stud 8:69-74

Janson J, Willemse MTM (1995) Pollen tube penetration and fertilization in Lilium longiflorum (Liliaceae). Am J Bot 82:197-196
Jobson RW, Albert VA (2002) Molecular rates parallel diversification contrasts between carnivorous plant sister lineages. Cladistics 18:127-136

Jobson RW, Playford J, Cameron KM, Albert VA (2003) Molecular phylogenetics of Lentibulariaceae inferred from plastid rps16 intron and trnL-F DNA sequences: implications for character evolution and biogeography. Syst Bot 28:157-171

Kausik SD (1938) Pollen development and seed formation in Utricularia caerulea. Beih Bot Zbl 58A:365-378

Kausik SB, Raju MVS (1955) A contribution to the floral morphology and embryology of Utricularia retriculata. Proc Indian Acad Sci $41: 155-166$

Khan R (1954) A contribution to the embryology of Utricularia flexuosa Vahl. Phytomorphol 4:80-117

Khan R (1992) Lentibulariaceae. In: Johri BM, Ambegaokar KB, Srivastava PS (eds) Comparative embryology of angiosperms II. Springer, Berlin, pp 755-762

Kirchoff BK, Pfeifer E, Rutishauser R (2008) Plant structure ontology: how should we label plant structures with doubtful or mixed identities? Zootaxa 1950:103-122

Koi S, Kato M (2010) Developmental morphology of seedling and shoot and phylogenetic relationship of Diplobryum koyamae (Podostemaceae). Am J Bot 97:373-387

Kopczyńska K (1964) Embryo sac development in Pinguicula vulgaris $\mathrm{L}$. Acta Soc bot Pol 33:141-156

Kościńska-Pająk M (2006) Biologia rozmnażania apomiktycznych gatunków Chondrilla juncea L., Chondrilla brevirostris L. i Taraxacum alatum Lindb. z uwzględnieniem badań ultrastrukturalnych i immunocytochemicznych. KonTekst Kraków 2006. pg. $1-104$

Kościńska-Pająk M, Bednara J (2006) Unusual microtubular cytoskeleton of the apomictic embryo sac of Chondrilla juncea L. Protoplasma 227:87-93

Krishna Iyengar CV (1941) Development of embryo-sac and endosperm haustoria in Torenia cordifolia Roxb., and T. hirsuta Benth. Proc Nat Inst Sci India 7:61-71

Laakkonen L, Jobson RW, Albert VA (2006) A new model for the evolution of carnivory in the bladderwort plant (Utricularia):adaptive changes in cytochrome $\mathrm{c}$ oxidase $(\mathrm{COX})$ provide respiratory power. Plant Biol 8:758-764 http://www.ncbi.nlm.nih.gov/sites/entrez? cmd $=$ Retrieve \&db=PubMed\&list_uids $=17203431 \& d o p t=$ Abstract. doi:10.1055/s-2006-924459

Lang FX (1901) Untersuchungen über Morphologie, Anatomie und Samenentwicklung von Polypompholyx und Byblis gigantea. Flora 88:149-206

Li DX, Lin MZ, Wang YY, Tian HQ (2009) Synergid: a key link in fertilization of angiosperms. Biol Plant 53:401-407

Marton ML, Cordts S, Broadhvest J, Dresselhaus T (2005) Micropylar pollen tube guidance by egg apparatus 1 of maize. Science 307:573-576

Masand P, Kapil RN (1966) Nutrition of the embryo sac and embryo-a morphological approach. Phytomorphology 16:158-175

Merl EH (1915) Beiträge zur Kenntnis der Utricularien und Genlisen. Flora 108:127-200

Merz M (1897) Untersuchungen über die Samenentwicklung der Utricularien. Flora 84:69-87

Meyer R, Stubbe W (1974) Das Zahlenverhältnis von mütterlichen und väterlichen Plastiden in den Zygoten von Oenothera erythrosepala Borbas (syn. Oe. lamarckiana). Ber Deutsch Bot Ges 87:29-38

Mogensen HL (1978) Synergids of Proboscidea louisianica (Martiniaceae) before fertilization. Phytomorphology 28:114-122. doi:10.1007/s00709-008-0020-9

Müller K, Borsch T (2005) Phylogenetics of Utricularia (Lentibulariaceae) and molecular evolution of the trnK intron in a lineage with high substitutional rates. Plant Syst Evol 250:39-67. doi:10.1007/s00606-004-0224-1 
Müller K, Borsch T, Legendre L, Porembski S, Barthlott W (2000) A phylogeny of Lentibulariaceae based on sequences of matK and adjacent non-coding regions. Am J Bot 87:145-146

Müller K, Borsch T, Legendre L, Porembski S, Theisen I, Barthlott W (2004) Evolution of carnivory in Lentibulariaceae and the Lamiales. Plant Biol 6:477-490

Olson AR, Cass DD (1981) Changes in megagametophyte structure in Papaver nudicaule following in vitro placental pollination. Am J Bot 68:1333-1341

Płachno B (2002) Embryology of section Calpidisca members: Utricularia livida E. Meyer and Utricularia sandersonii Oliver (Lentibulariaceae). MSc thesis. The Jagiellonian University, Cracow (in Polish)

Płachno BJ, Świątek P (2008) Cytoarchitecture of Utricularia nutritive tissue. Protoplasma 234:25-32

Płachno BJ, Światek P (2009) Functional anatomy of the ovule in Genlisea with remarks on ovule evolution in Lentibulariaceae. Protoplasma 236:39-48. doi:10.1007/s00709-009-0045-8

Płachno BJ, Świątek P (2010) Unusual embryo structure in viviparous Utricularia nelumbifolia, with remarks on embryo evolution in genus Utricularia. Protoplasma 239:69-80. doi:10.1007/s00709009-0084-1

Płachno BJ, Wołowski K (2008) Algae commensals community in Genlisea traps. Acta Soc Bot Pol 1:77-86

Płachno BJ, Kozieradzka-Kiszkurno M, Świątek P (2007) Functional ultrastructure of Genlisea (Lentibulariaceae) digestive hairs. Ann Bot (Lond) 100:195-203. doi:10.1093/aob/mcm109

Płachno BJ, Clivati D, de Miranda VFO, Świątek P (2009) Are there seed pedestals in Lentibulariaceae? Acta Biol Cracov Bot 5:115118

Poddubnaya-Arnoldi VA (1976) Tsitoembriologiya pokrytosyemyennykh rasteniy. Nauka, Moskva

Punwani JA, Drews GN (2008) Development and function of the synergid cell. Sex Plant Reprod 21:7-15

Rajan SS, Kumar DJ (1974) Embryological studies in Lentibulariaceae I. Floral morphology and embryology of Utricularia smithiana, Wt. Ic. Proc Plant Sci 80:18-25

Richter-Landmann W (1959) Der Befruchtungsvorgang bei Impatiens glandulifera Royle unter Berücksichtigung der plasmatischen Organelle von Spermzelle, Eizelle und Zygote. Planta 53:162177

Russell SD (1987) Quantitative cytology of the egg and central cell of Plumbago zeylanica and its impact on cytoplasmic inheritance patterns. Theor Appl Genet 74:693-699
Russell SD, Cass DD (1988) Fertilization in Plumbagella micrantha. Am J Bot 75:778-781

Rutishauser R, Moline P (2005) Evo-devo and the search for homology ("sameness") in biological systems. Theory Biosci 124:213-241

Rutishauser R, Novelo RA, Philbrick CT (1999) Developmental morphology of New World Podostemaceae: Marathrum and Vanroyenella. Int J Plant Sci 160:29-45

Schulz R, Jensen WA (1968) Capsella embryogenesis: The synergids before and after fertilization. Am J Bot 55:541-552

Shivaramiah G (1967) Observations on the floral morphology and embryology of Utricularia stricticaulis Stapf. Proc Plant Sci 65:56-62

Siddiqui SA (1978a) Studies in the Lentibulariaceae 8. The development of gametophytes in Utricularia dichotoma Labil. Flora 167:111-116

Siddiqui SA (1978b) Studies in the Lentibulariaceae 9. Pollination, fertilization, endosperm, embryo and seed in Utricularia dichotoma Labill. Bot Jahrb Syst Pflanzen Pflanzengeographie 100:237-245

Siddiqui SA (1979) Lentibulariaceae 11. The development of endosperm and embryo in Utricularia cornuta Mixch. Proc Indian Acad Sci 88:213-217

Sirová D, Borovec J, Černá B, Rejmánková E, Adamec L, Vrba J (2009) Microbial community development in the traps of aquatic Utricularia species. Aquat Bot 90:129-136

Sirová D, Borovec J, Černá B, Rejmánková E, Adamec L, Vrba J (2010) Utricularia carnivory revisited: plants supply photosynthetic carbon to traps. J Exp Bot 90(2):129-136

Taylor P (1989) The genus Utricularia - a taxonomic monograph. Kew B 14:1-735

Teryokhin ES, Nikiticheva ZI (1981) The family Orobanchaceae ontogeny and phylogeny. Leningrad "Nauka," Leningrad

Thijssen MH, Mittempergher F, Van Aelst AC, Van Went JL (1997) Improved ultrastructural preservation of Petunia and Brassica ovules and embryo sacs by high pressure freezing and freeze substitution. Protoplasma 197:199-209

Tilton VR (1981) Ovule development in Ornithogalum caudatum (Liliaceae) with a review of selected papers on angiosperm reproduction IV. Egg apparatus structure and function. New Phytol 88:505-531

Went JL (1970) The ultrastructure of the synergids of Petunia. Acta Bot Neerl 19:121-127

Wylie R, Yocom AE (1923) The endosperm of Utricularia. U Iowa Stud Nat History 10(3-18):32 